\title{
ENCOURAGING AND DISCOURAGING FACTORS FOR NETWORKING AMONG TECHNOLOGY FIRMS: A CASE STUDY IN THE TECHNOLOGY, INNOVATION AND KNOWLEDGE FIRMS NETWORK (TIKFN)
}

\author{
ANDRÉA A. C. MINEIRO ${ }^{1}$ \\ http://orcid.org/0000-0003-1155-7333 \\ DONIZETI L. SOUZA 2 \\ https://orcid.org/0000-0002-4555-394X \\ LUIZ G. R. ANTUNES 3 \\ (iD) https://orcid.org/0000-0003-2997-2949 \\ CLEBER C. CASTRO ${ }^{4}$ \\ (D) https://orcid.org/0000-0002-6443-9501
}

To cite this paper: Mineiro, A. A. C., Souza, D. L., Antunes, L. G. R., \& Castro, C. C. (2019). Encouraging and discouraging factors for networking among technology firms: A case study in the technology, innovation and knowledge firms network (TIKFN). Revista de Administração Mackenzie, 20(3). doi:10.1590/1678-6971/eRAMR190139

Submission: Aug. 16, 2018. Acceptance: Oct. 22, 2018.

\footnotetext{
1 Universidade Federal de Itajubá (Unifei), Itajubá, MG, Brazil. Universidade Federal de Lavras (Ufla), Lavras, MG, Brazil.

2 Instituto Federal do Sul de Minas (IFMG), Três Corações, MG, Brazil.

3 Instituto Federal de Minas Gerais (IFMG), Formiga, MG, Brazil.

4 Universidade Federal de Lavras (Ufla), Lavras, MG, Brazil.
}

\section{(cc) BY This is an open-access article distributed under the terms of the Creative Commons Attribution License.}

\footnotetext{
This paper may be copied, distributed, displayed, transmitted or adapted if provided, in a clear and explicit way, the name of the journal, the edition, the year and the pages on which the paper was originally published, but not suggesting that RAM endorses paper reuse. This licensing term should be made explicit in cases of reuse or distribution to third parties. It is not allowed the use for commercial purposes.

Este artigo pode ser copiado, distribuído, exibido, transmitido ou adaptado desde que citados, de forma clara e explícita, o nome da revista, a edição, o ano e as páginas nas quais o artigo foi publicado originalmente, mas sem sugerir que a RAM endosse a reutilização do artigo. Esse termo de licenciamento deve ser explicitado para os casos de reutilização ou distribuição para terceiros. Não é permitido o uso para fins comerciais.
} 


\section{ABSTRACT}

Purpose: The aim of this article is to identify which factors encourage and/or discourage companies to operate as a network, based on the Technology, Innovation and Knowledge Firms Network (TIKFN).

Originality/value: Few advances have been made in the literature to understand the technology-based firms' cooperation networks (TBFs), which have different characteristics, especially in relation to levels of uncertainty and innovation.

Design/methodology/approach: It was conducted a Study Case on this paper. Therefore, data were collected through documents, semi structured questionnaires and focal groups to assure data source triangulation. Additionally, data analysis consisted of networks structural analysis, regression analysis and content analysis by frequency and category.

Findings: Among the observed results, it is noticeable that congruence of objectives, length of participation and network strengthening represent the encouraging factors for network operation. On the other hand, asymmetric interests, low actors' engagement and lack of active management are the discouraging factors. In order to assure the credibility of this study, results were evaluated through two focal groups composed by the network managers and participants, thus increasing the authenticity of the study. Results can be considered relevant as they contribute to understand the behavior of technology companies in a network, whose characteristics differ from other interorganizational networks especially regarding uncertainty levels and access to resources and information.

\section{KEYWORDS}

Technology-based firms (TBF). Cooperative networks. Encouraging and discouraging factors. Network structural analysis. TBFs network. 


\section{INTRODUCTION}

In the past decades, studies involving cooperative networks have emerged on several fields of knowledge. This has been an increasing phenomenon on organizational studies by means of the resources dependence theory, social networks, critical and institutional theory, among other theoretical perspectives (Ebers, 2015; Balestrin, Verschoore, \& Reyes, 2010).

Andrighi, Hoffmann and Andrade (2011) remark that most network investigations in Applied Social Studies address different frameworks of the production model in order to obtain competitive advantage. Moreover, cooperative behavior, communication and trust among actors are commonly researched in this field.

Therefore, the concern of the researchers is to understand the network structure by means of cooperative behavior among different actors, communication through information and learning exchange between members and trust behavior within the network. Such understanding enables an evaluation on levels of cooperation, all the way from an analysis of the encouraging precedents for stablishing a network, throughout its results and to the discouraging factors for its existence (Xavier, Paiva, Alves, \& Medeiros, 2015; Wegner \& Padula, 2012; Andrighi et al., 2011; Balestrin et al., 2010).

For instance, in literature, several encouraging factors for network operation are presented, such as: access to strategic resources and competences, new knowledge acquisition, economies of scale and/or objectives scope and congruence (Ebers, 2015; Mendonça, Teixeira, Bernardo, \& Fonseca Netto, 2012; Chauvet, Chollet, Soda, \& Huault, 2011; Balestrin et al., 2010). Regarding discouraging factors for network operation, the profile of participating companies, such as economic, strategic and structural characteristics, may generate opportunism, mistrust and uncertainty within relationships (Xavier et al., 2015, Wegner \& Padula, 2012).

In the innovation context, Dias, Hoffmann and Martínez-Fernández (2016) indicate that cooperative networks in complex innovative environments can facilitate the development of new products, services or processes, which allows for complementary and specificity actions to keep interdependent relationships in a particular dynamic.

Hence, cooperative networks emerge as effective strategies to overcome technology-based firms' (TBFs) difficulties by bringing new perspectives to sharing knowledge and learning, fundamental to the technological innovation 
process, and facilitating resources, products, services and information exchange (Löfsten, 2016; Tálamo \& Carvalho, 2012; Franco \& Haase, 2011). Furthermore, a mapping of technology networks enables to understand how technology behaves and how humans respond to it. Such understanding may enhance individual business strategies and technological innovation policies of companies or industries (Alstott, Triulzi, Yan, \& Luo, 2017).

However, in spite of the subject's increase on both national and international contexts (Andrighi et al., 2011; Balestrin et al., 2010), there has been little advance regarding TBFs' cooperative networks.

Some international studies describe how the immersion of actors in TBFs' networks influence the network structure based on a structural analysis (Gilsing, Cloodt, \& Bertrand-Cloodt,, 2016). Chuluun, Prevost and Upadhyay (2017) research how connectivity characteristics among technology networks affects TBFs' innovation. Napolitano, Evangelou, Pugliese, Zeppini and Room (2018) analyzed the structure of technology networks and evaluated their relevance in the dynamics of innovation patenting.

In the Brazilian context, Castro (2010) identified, in the value chain of TBFs located in Florianopolis, the means and points of cooperation based on the concept of cooperative networking of small and medium-sized enterprises. Souza (2014) explained how adopting innovation and networking practices might help on products and services development and on process improvement in a TBFs' network. Moreover, Desidério and Popadiuk (2015) state that in small-sized TBFs, the paradox of cooperating to compete becomes even more necessary, given the structural and financial limitations to enter research and innovation networks.

However, a study gap in the context of TBFs can be noticed, regarding comprehension of encouraging and discouraging factors for network establishment of TBFs with distinct characteristics, especially on uncertainty levels, intensive knowledge use and innovation levels (Gilsing et al., 2016; Li \& Qian, 2008; Valério Netto, 2006). Thus, the problem of this research intends to fill this gap.

Accordingly, the aim of this article is to identify the factors that encourage and/or discourage TBFs to operate as a network, based on the Technology, Innovation and Knowledge Firms Network (TIKFN). Hence, these specific objectives were established: 1. describe TIKFN and its structural characteristics; 2. identify encouraging and discouraging factors for network operation; and 3. compare of obtained results on focal groups composed by TIKFN associated members. 
Besides this introduction, this article includes other four sections. The second section addresses theoretical aspects regarding network structural analysis, encouraging and discouraging factors for network operation, and TBFs' cooperative networks. The third section defines the research method. The fourth section shows results and discussion and, finally, the last section presents final considerations, limitations and propositions to future studies.

\section{THEORETICAL BACKGROUND}

Three aspects are covered on the theoretical background. Firstly, the main concepts regarding network structural analysis are presented, focusing on measures employed in the analysis of position, connection and flow in a social network. In addition, some network operation encouraging and discouraging factors are addressed. Finally, TBFs' specificities on network operation are discussed, allowing for new insights on cooperative networking.

\subsection{Network structural analysis}

World globalization has made the organizational environment increasingly more competitive, hence the interest on studies of cooperative network as a means to obtain competitive advantage, through the paradox of cooperate to compete (Lacoste, 2012; Balestrin et al., 2010). Among different cooperative network approaches, it is noticeable that social networks analysis represents a powerful social phenomena investigation tool, in order to identify cooperative structures, coordination and/or trust among social groups or phenomena (Steketee, Miyaoka, \& Spiegelman, 2015; Scott, 2013).

The social network analysis can be employed to measure and analyze structural characteristics of networks such as connections, resources, informational bonds, among other interactions. The aim is to understand how a network structure provides opportunities and/or restrictions to actors, constraining or enabling access to resources, information and behaviors (Ebers, 2015; Steketee et al., 2015; Alhajj \& Rokne, 2014; Scott, 2013).

A representation of a set of ties (actors/organizations) and a set of lines (ties between actors) is the basis for the network structural analysis, resulting in significant use of graphs concepts and theorems (Chiesi, 2015). Borgatti and Foster (2003) assert that network structural analysis allow for a systematic study of actors or organizations, their positions in a network, 
the existing connections, the information flow and the network density and participating actors and/or organizations degree of centrality indexes.

Among the networks structural analysis metrics, two are considered relevant: 1. degree of centrality, represented by more or less central positions of each actor or organization in a social network; and 2. degree of density, a result of the ratio between the number of existing relationships in a network and the total of possible relationships (Alhaji \& Rokne, 2014; Scott, 2013; Limieux \& Ouimet, 2008; Nohria, 1992).

Moreover, it should be noticed that the importance of network structural analysis is related to strategic objectives of organizations. Nonetheless, strategic objectives are considered to be created and reformulated according to encouraging and discouraging factors for each organization to operate in a given cooperative network (Arya \& Lin, 2007). Therefore, it is necessary to discuss encouraging (precedents) and discouraging factors for network operation, enabling a more holistic analysis of actors' behavior on a given social network.

\subsection{Encouraging and discouraging factor for network operation}

Cooperative networks are a group of organizations collaborating with each other, through horizontal and vertical relationships, in order to achieve common goals (Mendonça et al., 2012). In addition, networking enables access to resources, information and knowledge that are hard to obtain through other social means, which can contribute to innovation processes and bring new business opportunities (Chauvet et al., 2011; Borgatti \& Foster, 2003; Nohria, 1992).

Hernandes and Giglio (2014) remark that the necessary conditions to form networks can be understood by rational-economic and social paradigms. The rational-economic paradigm is centered on the resource dependence theory, indicating that a cooperative network result from better competitive advantages to firms, which pursue better market positioning. In this paradigm, access to markets and technologies, economic advantage, knowledge, material resources, decrease in risks and uncertainty, access to information, new opportunities, ability to respond, flexibility, economy of scope and scale and network participation in order to defend a leading position and to achieve competitive advantages, such as innovation, quality and cost reduction are encouraging aspects of forming networks (Balestrin \& Verschoore, 2016; Xavier et al., 2015; Hernandes \& Giglio, 2014; Balestrin et al., 2010; Giglio, Rimoli, \& Silva, 2008; Klerk \& Kroon, 2008; Grandori \& Soda, 1995; Powell, 1990). 
On the other hand, the social paradigm assumes that relationships constitute the orientational and behavioral background of actors as its basic premise. In this paradigm, the identified encouraging aspects of forming networks are reliable relationships, commitment, legitimacy, interdependence, previous social relationships, contacts, values, transparency, culture of actors, among others (Giglio \& Macau, 2015; Bertoli, 2014; Hernandes \& Giglio, 2014; Balestrin et al., 2010; Giglio et al., 2008; Klerk \& Kroon, 2008; Rimoli \& Giglio, 2008).

However, despite the benefits (encouraging factors) brought by networks, there are empirical evidences regarding a low life cycle of firms' networks. Some actors hypothesize that firm's networks are created at the same rate that they are finished (Xavier et al., 2015). Many networks are formed to overcome immediate difficulties and lack a strategic view that comprehends market share. This results on networks being constituted and terminated upon solving punctual issues. Hence, a network management to create longterm strategies is a key success factor (Balestrin \& Verschoore, 2016).

Several authors remark the importance of analyzing networks under a critical perspective, given that a large amount of studies on cooperative networks focus only on successful cases, as well as on the positive aspects of cooperative-based management. Nevertheless, little attention is paid to failure cases, as well as difficulties and conflicts involving cooperation-based management (Wegner \& Padula, 2012; Pereira, Venturini, Wegner, \& Braga, 2010; Nordin, 2006).

Highlighted among other discouraging factors for networking, concerning the rational-economic paradigm, are: the participating companies profile, as economic, strategic and structural characteristics might generate opportunistic relationships, mistrust and uncertainty; lack of synergy in objectives and cooperation; rivalry among participants; structural and strategic maladjustment; different sizes of participating companies, process failure on network management and coordination; little cost-benefit ratio; strategic problems (risk of losing essential skills to a partner); and the result of alliances (low performance, as divisions may be considered unfair) (Xavier et al., 2015; Wegner \& Padula, 2012; Pereira et al., 2010; Nordin, 2006).

Regarding discouraging factors for networking, concerning the social paradigm, there can be noticed: lack of commitment, aversion to changes, interests asymmetry, information asymmetry, individualistic situations and cultural aspects of each member, lack of cooperation among the involved people, insufficient communication and conflicts among actors (Xavier et al., 2015; Barcellos, Borella, Peretti \& Galelli, 2012; Wegner \& Padula, 2012; Pereira et al., 2010; Nordin, 2006). 
In brief, Figure 2.2.1 summarizes the main evidences of encouraging and discouraging factors for network operation.

\section{(Figure 2.2.1)}

\section{ENCOURAGING AND DISCOURAGING FACTORS}

\begin{tabular}{|c|c|c|}
\hline Factors/paradigm & Rational-economic & Social \\
\hline Encouraging & $\begin{array}{l}\text { Access to markets, technologies and } \\
\text { innovations; } \\
\text { Obtaining economic advantages; } \\
\text { Reduction of risks and uncertainties; } \\
\text { New business opportunities; } \\
\text { Economies of scale and scope; } \\
\text { Obtaining a leading position; } \\
\text { Acquiring competitive advantages. }\end{array}$ & $\begin{array}{l}\text { Trust relationships; } \\
\text { Legitimacy; } \\
\text { Maintenance of previous social } \\
\text { relationships; } \\
\text { Shares values and culture of } \\
\text { actors. }\end{array}$ \\
\hline Discouraging & $\begin{array}{l}\text { Differences on profile and size of } \\
\text { participating companies; } \\
\text { Opportunism relationships; } \\
\text { Lack of synergy of objectives; } \\
\text { Rivalry among participants; } \\
\text { Strategic and structural } \\
\text { maladjustments; } \\
\text { Coordination challenges; } \\
\text { Little cost-benefit ratio. }\end{array}$ & $\begin{array}{l}\text { Lack of commitment and } \\
\text { cooperation; } \\
\text { Interests and information } \\
\text { asymmetry; } \\
\text { Insufficient communication; } \\
\text { Conflicts among actors. }\end{array}$ \\
\hline
\end{tabular}

Source: Elaborated by the authors.

Encouraging and discouraging factors are emphasized in the literature, however TBFs particularities and behaviors demand for elucidation.

\subsection{Networks of technology-based firms (TBFs)}

TBFs have a high degree of knowledge within they commercialized product/service, being recognized by their short life cycle of products, aggressive market dynamics and high marketing investments (Li \& Qian, 2008; Valério Netto, 2006).

When compared to traditional firms, TBFs changes of success are smaller, mainly due to difficulties on transforming a technology into a firm and to the lack of managerial skills by researchers, given that these are not businesspersons yet. Moreover, an innovating product requires a large amount of investments and faces high non-acceptance risks in the market (Engelman, Fracasso, \& Brasil, 2011). 
In the cooperative networking point of view, TBFs are defined as production networks and opportunities of access to resources and learning, where structural relationships of power are minimized, horizontal agents and most relationships are cooperative, spreading through knowledge exchange in order to develop innovations and technologies (Andrade \& Torkomian, 2008; Côrtes, Pinho, Fernandes, Smolka, \& Barreto, 2005). Furthermore, TBFs' networks can be considered means for companies to obtain access to complementary resources and to knowledge of partners (Gilsing et al., 2016).

TBFs' networks are also identified as formal and informal networks. Formal networks are stablished with credit providers, such as venture capitalists, banks, creditors, commercial associations, etc. Conversely, informal networks include personal relationships, family ties and business partners (Löfsten, 2016).

Among studies that aimed to investigate TBFs insertion in cooperative networks, the study of Côrtes et al. (2005) can be highlighted, as they approached cooperation and constitution of innovation-bound networks in Brazilian TBFs. Among the observed results, the authors demonstrated that the adoption of cooperative mechanisms among TBFs is still limited and focused on relationships with academic institutions, being considered lowdensity networks with weak ties between actors.

Côrtes et al. (2005) state that strong ties enhance TBFs growth, especially on specific niches. As for weak ties, they allow TBFs to overcome rigid structural issues, even if at first such arrangement is not the most favorable to innovative performance.

Regarding relationships, Franco and Haase (2011) highlight that networks affect TBFs performance, mainly on the amount and diversity of partnerships, the quality of the constituted network, the access to technological sources, the specificity of shared resources and the development of relevant relationships. Additionally, Chuluun et al. (2017) research how connectivity among technology networks affect TBFs' innovation and the perception of market participants regarding the risk of innovation.

Finally, Andrade and Torkomian (2008) concluded that TBFs' relationship networks are defined by different specificities, such as: 1 . relevant informal relationships, especially in the beginning of enterprises, which might behave both as strong ties (close contacts and friends) and weak ties (information availability); and 2. highly specific collaborative relationships between firms. The authors suggest that TBFs' networks tend to present low-density levels (relationships among actors), as the few existing relationships are high- 
intensity ones, which contribute to a low-confidence environment and little reciprocity to the other firms in a network.

Therefore, TBFs' networks structures are generally fragile and present unformed governance mechanisms, which discourages the formation and maturity of a solid cooperative structure among participants. Such factors lead to new considerations on competition between TBFs and motivate new studies on encouraging and discouraging factors that may strengthen the performance of TBFs on cooperative networks.

\section{RESEARCH METHOD}

The study was developed at TIKFN, located in Itajubá, Minas Gerais, Brazil, which has the mission to promote economic development through sharing technology, innovation and knowledge. The network was conceptualized in 2012 in the facilities of the Science and Technology Park of Itajubá, and came to be on 2014, because of the growth potential of the information and communications technology (ICT) sector in the region and the support of partners.

In 2016, it obtained the title of Municipal Public Utility by Law n. 3712, of October 17, 2016 and it coordinates the governance of the Technology Cluster of Itajubá (TCI) by the technical note n. 001/2016 from the Economic Development Secretary of State.

In order to investigate a representative case, the analysis of the TIKFN's cooperative networks was elected. TIKFN pursues generating new businesses and opening new markets, both national and internationally, for its participating technology-based companies. This network is constituted of 35 TBFs, 23 of which are focused on the fields of ICT, developing products and services that involve infrastructure, platform and software, 10 of which are in the power industry (developing and commercializing solutions to the energy sector) and two of which specialize in biomedicine (TBFs that develop and commercialize solutions to the health sector). This network was chosen due to its public utility to the region and to the access clearance to all firms within the network. The companies have joined the network in order to obtain further recognition and vigor of micro and small-sized TBFs from the city, as well as to share knowledge and be a productive technology and innovation chain

The choice of case study as the research method is supported by Eisenhardt (1989), who defined it is a method that enables a type of critical 
and profound analysis of an investigation phenomenon. A mix of methods was employed, by combining quantitative and qualitative approaches, which allows for a better understanding of the research problem than an isolated approach (Creswell \& Clark, 2006).

In order to collect data, semi structured questionnaires were submitted to all firms within the network, documents and, lastly, focal groups, which defines a sequential triangulation, as mentioned by Morse (1991) and Vergara (2015). The use of data triangulation by means of data collection ensures credibility and confirmability to the work, given that obtained results are trustworthy and approved by the own builders of the studied social reality (Lincoln \& Guba, 1986; Godoy, 2005).

The questionnaires were collected, after contacting all owners and/or partners of firms via phone, through Google docs ${ }^{\circledR}$, between the months of January and February 2017. All network participating firms answered to the questionnaire, resulting in $100 \%$ of response. The aim of the questionnaire was to evaluate, based on the managers' perception, the structure of existing relationships, the precedents to network participation, as well as the main encouraging and discouraging factors that influence their network participation.

Moreover, documental researches were carried along with TIKFN managers, in order to evaluate information regarding their fields, as well as the length of the participation of each firm in this network.

Data were analyzed on the Ucinet ${ }^{\circledR}$ (Borgatti, Everett \& Freeman, 2002) and NetDraw ${ }^{\circledR}$ (Borgatti, 2002) softwares for structural network analysis, focused on the graph matrix construction and on the calculation of participating actors' centrality and network density to identify groups and possible subgroups in TIKFN. It is relevant to highlight that the only reason why this analysis was possible is because data was collected from the entire population (Limieux \& Ouimet, 2008). Additionally, the software Gretl® was employed to compare exit centrality to the length of the firm's participation in the network through regression analysis.

Moreover, a content analysis by frequency was adopted to understand the encouraging and discouraging factors for network operation. The content analysis by frequency consists of identifying interviewees' answers and grouping according to each question, by means of descriptive statistics (Bardin, 2016).

Finally, the results were presented and evaluated by the network participants through two focal groups (G1 and G2, respectively), one formed by representants of TIKFN's board of directors (identified as D1, D2 and D3) 
and the other one formed by network associated businesspersons (identified as A1, A2, A3, A4, A5 and A6). The groups were performed between the months of May and September 2017. Servo and Araújo (2012) state that focal groups may easily obtain data in a collective manner and, in a deeper level, they may be formed by a selected group of people to discuss a given topic. Silva, Veloso and Keating (2014) point out that the focal group may be used in the final stage of the research to discuss obtained results and to identify new evidences. Such strategy has proven itself important, as Godoy (2005) remarks that the results discussion with participating groups reinforces the precision and relevance of the work, besides granting credibility and authenticity to the study.

In brief, the research method is presented on Figure 3.1.

(Figure 3.1)

RESEARCH METHOD

\begin{tabular}{llll}
\hline $\begin{array}{l}\text { Specific } \\
\text { objective }\end{array}$ & $\begin{array}{l}\text { Description of the network } \\
\text { and its structural } \\
\text { characteristics }\end{array}$ & $\begin{array}{l}\text { Identify encouraging } \\
\text { and discouraging factors } \\
\text { for network operation }\end{array}$ & $\begin{array}{l}\text { Compare of obtained } \\
\text { results on focal groups }\end{array}$ \\
\hline $\begin{array}{l}\text { Data } \\
\text { collection }\end{array}$ & $\begin{array}{l}\text { Documents and } \\
\text { questionnaires }\end{array}$ & Questionnaires & Focal groups \\
\hline Data analysis & Structural network analysis & $\begin{array}{l}\text { Content analysis } \\
\text { (frequency) }\end{array}$ & $\begin{array}{l}\text { Content analysis } \\
\text { (category) }\end{array}$ \\
\hline
\end{tabular}

Source: Elaborated by the authors.

\section{RESULTS AND DISCUSSION}

The results analysis at TIKFN was divided in three steps: 1. description of TIKFN and its structural characteristics; 2. identification of encouraging and discouraging factors for network operation; and 3. comparison of the results obtained from two focal groups composed by TIKFN associated members.

\subsection{Description of TIKFN and its structural characteristics}

In order to analyze a networks structure, all participants were asked to attribute a 0 (inexistent) to 5 (very high) grade to the types of relationship among the other firms constituting the network. Based on the answers it 
was possible to generate a graphic structure of the network, highlighting the types of existing ties as well as the degree of exit centrality for each participating firm, as presented on Figure 4.1.1.

\section{(Figure 4.1.1)}

\section{STRUCTURE OF TIKFN (TYPES OF TIES AND DEGREE OF CENTRALITY)}

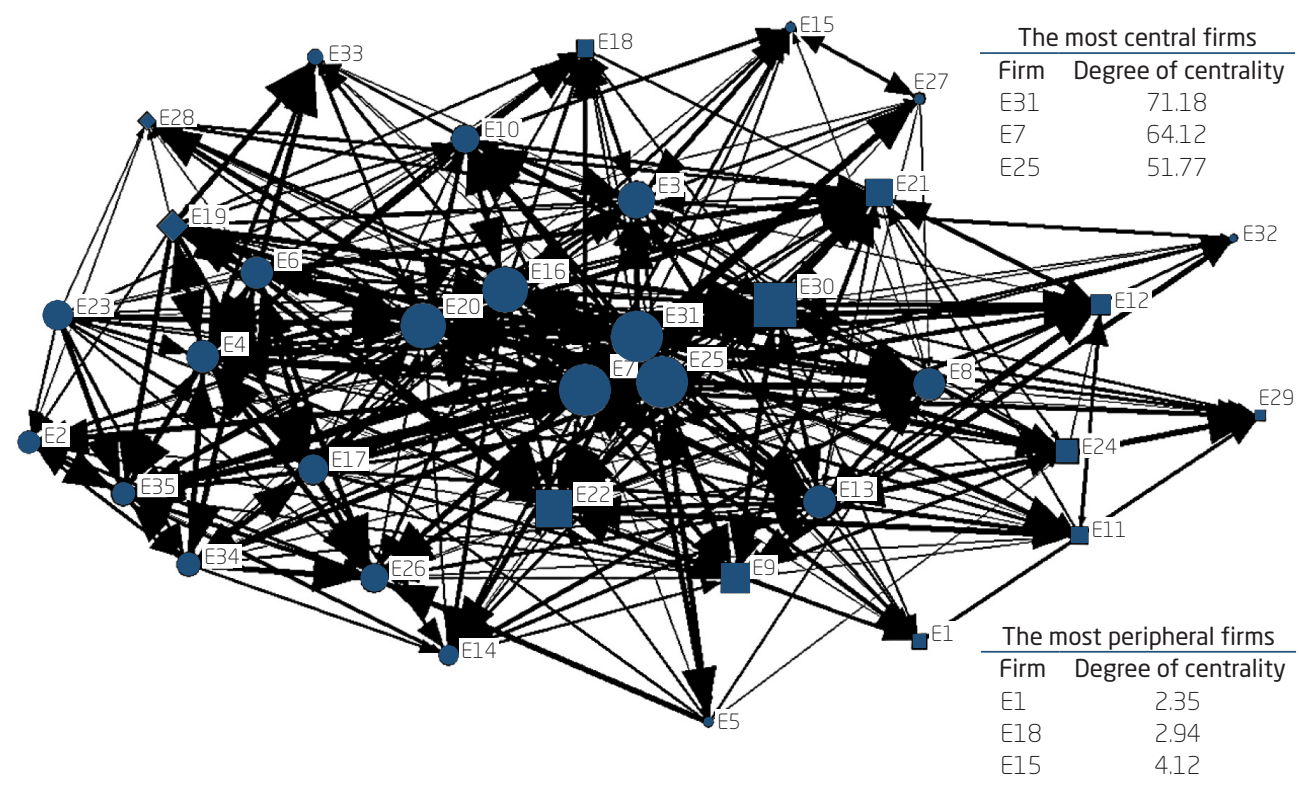

Source: Elaborated by the authors

The circles represent the firms in the ICT industry, the squares represent the firms in the energy industry and the rhombuses are the firms in the biomedical industry. The shapes representing the actors are organized in accordance to their degree of centrality, so that larger shapes represent the most central firms. Finally, the intensity of the ties (strong and weak) are represented by the thickness of lines, indicating the directions of relationships between actors.

The network structural analysis by intensity of relationships (strong and weak ties) enables to calculate firms' centrality by the exit and entrance degrees. The exit degree indicates the relationship perception of a specific firm towards the other firms in the network (from the individual to the collective level). The entrance degree, however, indicates the relationship perception of the other firms in the network towards one specific firm (from the collective to the individual level). It should be mentioned that as these are 
individual perceptions, entrance and exit levels of centrality are not always complementary, given that perception of relationships' intensity may vary.

Initially, an analysis of the exit centrality was performed. Figure 4.1.2 shows that firms "E31", "E7" and "E25" are the most central ones. Firm "E31" presents an exit centrality degree of 121.00, indicating that it has $71.18 \%$ of intensity of the possible relationships. The following most central firms are "E7" and "E25", with $64.12 \%$ and $51.77 \%$ of the possible relationships, respectively.

(Figure 4.1.2)

EXIST CENTRALITY - THE MOST CENTRAL AND PERIPHERAL ACTORS

\begin{tabular}{|c|c|c|c|c|c|}
\hline \multirow{2}{*}{ Firms } & \multicolumn{2}{|c|}{ Central } & \multirow{2}{*}{ Firms } & \multicolumn{2}{|c|}{ Peripheral } \\
\hline & Exit & $\%$ & & Exit & $\%$ \\
\hline E31 & 121.00 & 71.18 & E1 & 4.00 & 2.35 \\
\hline E7 & 109.00 & 64.12 & E18 & 5.00 & 2.94 \\
\hline E25 & 88.00 & 51.77 & E15 & 7.00 & 4.12 \\
\hline
\end{tabular}

Source: Elaborated by the authors.

Among the firms with the lowest exit centrality levels are "E1", "E15" and "E18", which are considered the most peripheral ones. As pointed by Nohria (1992), Scott (2013), and Alhajj and Rokne (2014) the centrality analysis allows for evaluating influence over existing relationships within a social network. At TIKFN, the most influent firms are "E31", "E7" and "E25". However, firms "E1", "E18" and "E15" are the least influent because of their few relationships with other firms in the network.

Regarding entrance centrality, Figure 4.1.3 shows that firms "E20", "E4" and "E35" are the most central ones. Firm "E20" presents a degree of 84.00 , indicating that is has $49.41 \%$ of intensity of the possible relationships. The following most central firms are "E4" and "E35", with $44.12 \%$ and $40 \%$ of the possible relationships, respectively. A common characteristic identified in firms with high entrance centrality degrees are that these are all providing services to several other firms in the network, which explains them being more frequently mentioned by the other firms in the network. It can be noticed that the most central firms are in the ICT sector. 


\section{(Figure 4.1.3)}

\section{ENTRANCE CENTRALITY - THE MOST CENTRAL AND PERIPHERAL ACTORS}

\begin{tabular}{ccccccc}
\hline \multirow{2}{*}{ Firms } & \multicolumn{2}{c}{ Central } & \multirow{2}{*}{ Firms } & \multicolumn{2}{c}{ Peripheral } \\
\cline { 2 - 3 } \cline { 7 - 7 } & Entrance & $\%$ & & & Entrance & $\%$ \\
\hline E20 & 84.00 & 49.41 & E23 & 5.00 & 2.94 \\
\hline E4 & 75.00 & 44.12 & E5 & 8.00 & 4.71 \\
\hline E35 & 68.00 & 40.00 & E32 & 10.00 & 5.88 \\
\hline
\end{tabular}

Source: Elaborated by the authors.

Among the most peripheral firms regarding the entrance centrality degree, there are "E23", "E5" and "E32" with $2.94 \%, 4.71 \%$ and $5.88 \%$ of intensity of the possible relationships, respectively, the three of them being in the ITC sector.

Through the analysis of the most central and peripheral firms by exit and entrance degree along with the length of operation in the network, it is possible to identify a relationship between variables. Comparing the five most central and the five most peripheral firms (exit centrality), it is possible to notice that all the most central ones have been operating in the network for a much longer time than the five most peripheral ones. The most central firms regarding entrance centrality have been operating in the network ever since its foundation. Among the most peripheral firms, only firm "E5" has not presented any relationship regarding the length of operation in the network, given that it has been in the network ever since its foundation and yet lies within the most peripheral ones.

In order to evaluate the relationship between the length of operation in the network and the degree of centrality, a regression analysis was performed, as presented on Figure 4.1.4. This analysis uses the degree of centrality that considers the existence of relationships among actors, regardless the intensity. 


\section{(Figure 4.1.4)}

REGRESSION MODEL (WITH HETEROSCEDASTICITY CORRECTION)

\begin{tabular}{lccc}
\hline \multicolumn{4}{c}{ Dependent variable: degree of centrality } \\
\hline \multicolumn{1}{c}{ Independent variables } & Coefficients & Ratio-t & P value \\
\hline Constant & -18.0936 & 8.27880 & $0.0361^{* *}$ \\
\hline In (length of network operation in months) & 8.7934 & 2.47520 & $0.0012^{*}$ \\
\hline Adjusted R-square & & 0.2547 & \\
\hline F test & & P value (F) & $0.001^{*}$ \\
\hline
\end{tabular}

* significant at $1 \%$; ** significant at $5 \%$.

Source: Elaborated by the authors.

The regression results show a positive coefficient between length of network operation and the firms' degree of centrality. Hence, the longer the firms have been in the network the higher their degree of centrality. In Social Sciences researching, Cohen (1988) suggests that the determining coefficient of $\mathrm{R}^{2}=0.02$ be considered as minor effect, $\mathrm{R}^{2}=0.13$ be considered as medium effect and $\mathrm{R}^{2}=0.26$ be considered as major effect.

Considering the criteria proposed by Cohen (1988), results indicate that the length of operation in the network presents determining coefficient of $\mathrm{R}^{2}$ with major effect over the degree of centrality in the network. Moreover, the $\mathrm{T}$ test of variables was significant at $5 \%$ level. The $\mathrm{F}$ test rejected the null hypothesis of all regression coefficients be zero, being significant at $1 \%$ level. Finally, it is noticeable that an adjusted R-square of 0.2547 indicates that approximately $25.47 \%$ of the degree of centrality variation in the analyzed firms can be explained by the model.

The intensity of relationships (thickness of lines) represents another important analysis metric (Limieux \& Ouimet, 2008). On Figure 4.1.1 it is possible to notice a higher frequency of strong ties among firms in the same industry, in comparison to the relationships stablished between firms from different fields.

Among the most evident sub networks, it is possible to identify a degree of density of $49 \%$ for energy firms and $47 \%$ for ICT firms when only interactions within their industries are analyzed. When analyzing relationships between firms in different industries, this percentage decreases to $22.4 \%$ for energy firms and $38.4 \%$ for ICT firms. Granovetter (1973) remarks that strong ties are heavily influenced by relationships of trust and commitment among the actors in the network. This is evidenced by the 
results, which identify a higher intensity of firms in the same industry and with longer time in the analyzed network, these being two factors that contribute to network operation.

In complex innovation environments, the participants of collaborative networks within the same social group tend to be more cohesive and prone to innovate, given that they depend on the benefits of trust, risk sharing and easy mobilization in order to facilitate the transfer of information and knowledge (Heinze, Shapira, Rogers, \& Senker, 2009). Therefore, it was intended to understand the network precedents (encouraging factors) and discouraging factors at TIKFN.

\subsection{Identification of encouraging and discouraging factors for network operation}

The respondents were asked to describe their main encouraging factors to be part of the network. Among the most frequent answers, it is noticeable the predominance of the strengthening of the network for higher acknowledgment in the region ( $42.86 \%$ of answers), this answer considers the political aspects such as interactions with local development agents, actions along with the government, strengthening of supporting institutions ecosystem, besides recognition of the TCI potential. Moreover, the responses of 1. partnership with other firms through integrated initiatives; and 2. possibility of new business opportunities correspond to $37.14 \%$ of the answers, respectively.

The most relevant item considers acknowledgment, which can be seen on the legitimacy features pointed by Grandori and Soda (1995) and Rimoli and Giglio (2008). This item reinforces the presence of the social paradigm pointed by Hernandes and Giglio (2014), which considers that relationships constitute the orientational and behavioral background of actors. Meanwhile, the other items are justified by social relationships and contacts (Rimoli \& Giglio, 2008; Giglio et al., 2008; Klerk \& Kroon, 2008), being the rationaleconomic paradigm the most present one (Hernandes \& Giglio, 2014). Because TIKFN is constituted of small TBFs, such results are justified by their limitation of financial and structural resources, which discourages an isolated performance, resulting on the need for cooperative strategies in order to assure higher ability to compete through joint initiatives and broadened business opportunities (Desidério \& Popadiuk, 2015).

Given the encouraging factors for network operation, the actors were questioned whether their expectations regarding participating in the 
network were achieved. Most of the respondents said that they expectations were satisfyingly achieved, with $42.86 \%$ of answers, followed by partial achievement of expectations, with $34.28 \%$ and not achieved, with $22.86 \%$ of answers.

Among those whose expectations were achieved, the most frequent reason was the strengthening and acknowledgment of TIKFN, with $28.57 \%$ of answers. There is also the emergence of new business opportunities and the increase of contacts within the network, with $22.86 \%$ of answers each.

On the other hand, those who had their expectations not achieved or partially achieved, identify the lack on involvement in network initiatives as a reason, with $31.43 \%$ of answers. These businesspersons acknowledge that, due to lack of time, there is no active participation in the network meetings, which contributes to the lack of commitment of several firms. In addition, the lack of effective actions (results) of the network and the conflicts of interests, with $17.14 \%$ of answers, respectively. Finally, aspects related to bureaucracy and partnership difficulties had $5.71 \%$ each.

Such results corroborate different studies on discouraging factors for cooperative network operation, to which interests' asymmetry, as well as management processes failures, may contribute to create isolated subgroups within the network, which is evidenced by the degree of density in the ICT and energy subgroups. Such conditions could encourage opportunism and mistrust, which may contribute to discourage cooperative initiatives, resulting in dissatisfaction among actors and low relevance of the benefits generated by the network (Xavier et al., 2015; Wegner \& Padula, 2012; Pereira et al., 2010).

Given the evidenced difficulties, the participants were asked to identify suggestions capable of contributing with the network strengthening and the firms' individual goals. Wegner and Padula (2012) reinforce that a cooperative network demands great coordination efforts, given that they are composed by culturally and managerially uneven firms, besides interests' asymmetry. This is confirmed in the analyzed case, where improvement of the network management is among the most frequent answers, with $37.14 \%$, mainly regarding demands' identification, improvement of benefits for involved firms and a more active performance by the managers.

Moreover, the development of new business opportunities was also mentioned as a suggestion, with $22.86 \%$ of answers. Some actors mentioned the strengthening of firms' commercial initiatives through a manager from TIKFN that may establish partnerships with other networks of firms or big companies in order to enable new businesses. 
Finally, actors point out the need for higher incentive to interactions and partnerships, and the network strengthening, with $20 \%$ of answers each. The actors suggest more frequent information exchange between firms, online meetings, and theme seminars provided by firms focusing on achievements and difficulties. On the networks strengthening, pursuing public policies to develop TCI can be highlighted, besides a broadened acknowledgment in the city and region in order to increase the firm's visibility. These characteristics are remarked by Balestrin and Verschoore (2016) and Côrtes et al. (2005), who advocate on interaction forms between members' and firms' growth encouraged by public policies. Moreover, the suggestions reinforce the proposal of Franco and Haase (2011) that networks affect the performance of TBFs, especially regarding the diversity of partnerships, the access to technological sources and shared resources.

\subsection{Comparison of results obtained on focal groups composed by TIKFN associated members}

The evaluation of results from the two focal groups (G1 and G2, represented by directors and businesspersons, respectively) happened during the following steps of results analysis: network structural analysis (considering exit and entrance centrality and degree of density), in the evidences of encouraging and discouraging factors for the networks, and in the suggestions to TIKFN. Figure 4.3.1 summarizes the obtained results by focal group, categorizing them as total, partial or no agreement regarding the presented results.

(Figure 4.3.1)

AGREEMENT LEVEL OF RESULTS BY FOCAL GROUPS

\begin{tabular}{lcc}
\hline & \multicolumn{2}{c}{ Focal groups } \\
\cline { 2 - 3 } & Group G1 & Group G2 \\
\hline Outcome/exit centrality & None & Partial \\
\hline Income/entrance centrality & Total & Total \\
\hline Degree of density & Total & Total \\
\hline
\end{tabular}


(Figure 4.3.1 (conclusion))

AGREEMENT LEVEL OF RESULTS BY FOCAL GROUPS

\begin{tabular}{lcc}
\hline & \multicolumn{2}{c}{ Focal groups } \\
\cline { 2 - 3 } & Group G1 & Group G2 \\
\hline Encouraging factors & Partial & Total \\
\hline Discouraging factors & Partial & Total \\
\hline Suggestions to TIKFN & Total & Total \\
\hline
\end{tabular}

Source: Elaborated by the authors.

A high level of agreement to the presented results is perceived, which reinforces the credibility of the study, as stated by Godoy (2005).

Regarding the network structural analysis, the directors on G1 mention that the exit centrality results focus on relationships between people, reflect on businesspersons' profiles and the way relationships are perceived.

Wegner and Padula (2012) emphasize the importance of the businessperson profile and the choices of the member to the network success. In this study, the businessperson profile was identified as a determining characteristic to the result of exit centrality, in other words, the businessperson's perception regarding the network was different from the way the network perceived him/her. Paiva and Fernandes (2012) argue that behavioral characteristics of entrepreneurs are relevant to the performance of their relationship in the network.

To G2, just one firm among the most central on exit centrality does not correspond to the result, because it is a new firm, the others are older than this one and this explains them having more interactions with network members, which agrees with Giglio and Macau (2015), Bertoli (2014), and Hernandes and Giglio (2014) regarding previous social relationships and contacts developed as part of a social angle present in networks participation.

In the entrance centrality, the groups agree with the firms' positions and confirm that they provide services within the network, which reinforces influence over existing relationships, as pointed by Nohria (1992), Scott (2013), and Alhajj and Rokne (2014).

Among encouraging factors for network operation, there were also oppositions among the responses of directors from G1. The similarities among the directors highlight the surprise regarding the answer to the ecosystem 
positioning and strengthening. The directors mentioned that they considered this answer as the least relevant, but saw the collective thinking among members in spite of solely individual interests as a positive point. This evidence of the network strength among other organizations and its legitimacy are emphasized by Nohria (1992), Grandori and Soda (1995), and Rimoli and Giglio (2008). A diverging point in literature was the access to resources as an encouraging factor (Ebers, 2015; Mendonça et al., 2012; Chauvet et al., 2011) that was not mentioned in the analyzed case, which was considered surprising by D1.

Regarding discouraging factors, there was only one point of disagreement related to the results, which was the bureaucracy in G1. Pereira et al. (2010) emphasize that management processes are factors capable of weakening network operation. Directors in G1 argue that there is no bureaucracy, given that documents required to enter TIKFN are common to any formalization. In G2, the members tried to demonstrate the situation when bureaucracy was present on the network formalization process.

The improvement suggestions were presented to groups, which agreed to the results and showed concern regarding real benefits for firms, being the category of most representativity. G1 stated that there are efforts in order for direct results to associates to be perceived. G2 shows the joint initiative among members, which is identified in the literature, because networking enables access to resources, information and knowledge that are hard to obtain through other social means, which can contribute to innovation processes and bring new business opportunities (Chauvet et al., 2011; Borgatti \& Foster, 2003; Nohria, 1992).

\section{FINAL CONSIDERATIONS}

The aim of this article was to identify the factors that encourage and/or discourage TBFs to operate as a network, based on the TIKFN. Hence, these specific objectives were established: 1. describe TIKFN and its structural characteristics; 2 . identify encouraging and discouraging factors for network operation; and 3. compare of results obtained on focal groups composed by TIKFN associated members.

For the first specific objective, it can be highlighted that TIKFN has three sectorial divisions, ICT, energy and biomedicine. The firms with the highest degree of centrality present the industry as a characteristic, being from the ICT industry, being also services providers within the network 
actors. This result highlights the commercial relationships inherent to the rational-economic paradigm proposed by Hernandes and Giglio (2014), perceived by the network structure. The firms with higher exit and entrance centrality have been on the network much longer than the five most peripheral firms, which was corroborated by the results of the regression analysis between the length of operation in the network and the degree of centrality of firms. It is shown that, among sub networks, it is possible to identify a higher degree of density of relationships within them, rather than of relationships with firms from different industries, which reinforces the proposal of Heinze et al. (2009), that companies within the same social group tend to be more cohesive and prone to innovating.

In the second specific objective, three encouraging factors are identified as more evidently shown in the researched firms: 1. congruence of objectives, 2. length of participation and 3. network strengthening.

The congruence of objectives is perceived when the participation and involvement of actors of the same industry are analyzed, as they are more active in comparison to interactions with firms from other industries. The length of participation in the network also contributes to a higher involvement because of established trust structures. The network strengthening for more acknowledgment was predominant, because actors understand that interactions with local agents, public, private and supporting institutions are fundamental to the network growth and to other initiatives capable of generating competitive advantages to firms. Such aspects are related to the social paradigm of Hernandes and Giglio (2014) and may reflect a sectorial characteristic, given that traditional studies on networks evidence aspects related to the rational-economic paradigm, encouraged by factors of economy of scale and costs of transactions (Balestrin \& Verschoore, 2016; Balestrin et al., 2010).

Regarding the discouraging factors for network operation, three factors were more evident in the researched firms: 1 . the existence of interests' asymmetry, 2. the low engagement of actors in the network and 3. the lack of active management. The presence of these factors encourage opportunism and mistrust, which contribute to discourage participants regarding the benefits generated by the network (Xavier et al., 2015; Wegner \& Padula, 2012; Pereira et al., 2010).

Among initiatives proposed by participants to strengthen the network, the need for improvement of the network management should be highlighted, through identification of the most latent demands for an action plan that focuses on improvement of coordination forms, higher involvement of firms 
and more effective results. Such results can contribute to an understanding on TBFs network behavior, whose characteristics differ from other organizations, especially regarding access to resources and information. Even though encouraging factors were based on social paradigm (Hernandes \& Giglio, 2014), improvement suggestions target specific initiatives to satisfy the economic needs of associated companies.

Referring to the third specific objective, when the results were presented and compared by associated members of TIKFN on focal groups, there were oppositions among the point of view of focal groups. The groups agree regarding entrance centrality results, difficulties and network suggestions. The disagreement occurs on exit centrality results and encouraging factors to enter the network. However, it should me mentioned that most results reflected the reality of TIKFN, which reinforces the authenticity of the study (Godoy, 2005).

Among the main contributions of the study, stand out the addition of structural analysis to support the identification of encouraging and discouraging factors for TBFs networks, besides the broadened understanding of TBFs' network behavior, whose characteristics differ from other interorganizational networks. Mainly regarding representativeness as an encouraging factor, which can be seen as a characteristic of sectorial TBFs' network, a collective interest is perceived as surpassing the individual interest in the formation of TIKFN

Even though the study is based on distinct data sources, which has allowed for increased comprehensiveness (network structural analysis) and depth (content analysis) of the researched phenomenon, the results must be cautiously analyzed, given that they are based on a specific network and does not enable generalization, hence this being one of the limitations of the research. However, the presented results are expected to generate new discussions and propositions to future studies, regarding both characteristics of networks of TBFs and the combination of structural analysis and encouraging and discouraging factors for network operation to characterize new studies on networks. 


\section{FATORES MOTIVADORES E INIBIDORES PARA A ATUAÇÃO EM REDES DE EMPRESAS DE BASE TECNOLÓGICA: UM ESTUDO DE CASO NA REDE DE EMPRESAS DE TECNOLOGIA, INOVAÇÃO E CONHECIMENTO (RETIC)}

\section{)}

\section{RESUMO}

Objetivo: O objetivo deste artigo é identificar os fatores que motivam e/ou inibem a atuação de empresas de base tecnológica em redes, tendo como base a Rede de Empresas de Tecnologia, Inovação e Conhecimento (Retic). Originalidade/valor: Poucos avanços são evidenciados na literatura para compreensão das redes de cooperação das empresas de base tecnológica (EBTs), as quais possuem características distintas, especialmente no que se refere aos níveis de incerteza e inovação.

Design/metodologia/abordagem: O método consiste em um estudo de caso, em que os dados foram coletados por meio de documentos, questionários semiestruturados e grupos focais, o que garantiu uma triangulação de fonte de dados. Os dados foram analisados por meio da análise estrutural de redes, análise de regressão e análise de conteúdo por frequência e temática.

Resultados: Observou-se que as congruências de objetivos, o tempo de participação e o fortalecimento da rede se mostraram os fatores motivadores para a atuação em rede. Por sua vez, a existência de assimetrias de interesses, a baixa participação dos atores e a falta de uma gestão atuante foram os fatores inibidores. Para garantir a credibilidade do estudo, os resultados foram avaliados por meio de dois grupos focais com gestores e participantes da rede, o que permitiu aumentar a autenticidade do estudo. Os resultados se mostraram relevantes ao contribuírem para o entendimento do comportamento de EBTs em rede, as quais possuem características distintas de outras redes interorganizacionais, especialmente no que se refere aos níveis de incerteza e às formas de acessar recursos e informações.

\section{PALAVRAS-CHAVE}

Empresas de base tecnológica. Redes de cooperação. Fatores motivadores e inibidores. Análise estrutural de redes. Redes de EBTs. 


\section{REFERENCES}

Alhajj, R., \& Rokne, J. (Eds.). (2014). Encyclopedia of social network analysis and mining. New York: Springer.

Alstottt, J., Triulzi, G., Yan, B., \& Luo, J. (2017). Mapping technology space by normalizing patent networks. Scientometrics, 110(1), 443-479. doi:10.10 07/s11192-016-2107-y

Andrade, R. F., \& Torkomian, A. L. V. (2008). Redes de relacionamento e perenidade das empresas de base tecnológica: Um estudo exploratório. Revista Ciências Administrativas, 14(1), 33-42. doi:10.5020/2318-0722.14. $1 . \% 25 \mathrm{p}$

Andrighi, F. F., Hoffmann, V. E., \& Andrade, M. A. R. (2011). Análise da produção científica no campo de estudo das redes em periódicos nacionais e internacionais. Revista de Administração e Inovação, 8(2), 29-54. doi:10.57 73/rai.v8i2.530

Arya, B., \& Lin, Z. (2007). Understanding collaboration outcomes from an extended resource-based view perspective: The roles of organizational characteristics, partner attributes, and network structures. Journal of Management, 33(5), 697-723. doi:10.1177/0149206307305561

Balestrin, A., \& Verschoore, J. (2016). Redes de cooperação empresarial: Estratégias de gestão na nova economia (2a ed.) Porto Alegre: Bookman.

Balestrin, A., Verschoore, J. R., \& Reyes, E. (2010). O campo de estudo sobre redes de cooperação interorganizacional no Brasil. Revista de Administração Contemporânea, 14(3), 458-477. doi:10.1590/S1415-65552010000 300005

Barcellos, P., Borella, M., Peretti, J., \& Galelli, A. (2012). Insucesso em redes de cooperação: Estudo multicasos. Revista de Gestão dos Países de Língua Portuguesa, 11 (4), 49-57.

Bardin, L. (2016). Análise de conteúdo (L. A. Reto \& A. Pinheiro, Trad.). São Paulo: Edições 70, Livraria Martins Fontes.

Bertoli, N. (2014). A confiança e o comprometimento como eixos organizadores dos estados de redes: Proposta conceitual e estudo de casos do agronegócio do norte do Paraná. Dissertação de mestrado, Universidade Paulista, São Paulo, SP, Brasil.

Borgatti, S. (2002). NetDraw network visualization. Harvard, MA: Analytic Technologies.

Borgatti, S. P., Everett, M. G., \& Freeman, L. C. (2002). Ucinet for Windows: Software for social network analysis. Harvard, MA: Analytic Technologies. 
Borgatti, S. P., \& Foster, P. C. (2003). The network paradigm in organizational research: A review and typology. Journal of Management, 29(6), 991-1013. doi:10.1016/S0149-2063(03)00087-4

Castro, L. F. T. (2010). Formação de rede de empresas de tecnologia da informação com base na análise da cadeia de valor. Dissertação de mestrado, Universidade Federal de Santa Catarina, Florianópolis, SC, Brasil.

Chauvet, V., Chollet, B., Soda, G., \& Huault, I. (2011). The contribution of network research to managerial culture and practice. European Management Journal, 29(5), 321-334. doi:10.1016/j.emj.2011.06.005

Chiesi, A. M. (2015). Network analysis. In J. D. Wright (Org.). International encyclopedia of the social \& behavioral sciences (2nd ed.). Orlando: Elsevier.

Chuluun, T., Prevost, A., \& Upadhyay, A. (2017). Firm network structure and innovation. Journal of Corporate Finance, 44, 193-214. doi:10.1016/ j.jcorpfin.2017.03.009

Cohen, J. (1988). Statistical power analysis for the behavioral sciences. Hilsdale. NJ: Lawrence Earlbaum Associates.

Côrtes, M. R., Pinho, M., Fernandes, A. C., Smolka, R. B., \& Barreto, A. L. (2005). Cooperação em empresas de base tecnológica: Uma primeira avaliação baseada numa pesquisa abrangente. São Paulo em Perspectiva, 19(1), 85-94. doi:10.1590/S0102-88392005000100007

Creswell, J. W., \& Clark, V. L. P. (2006). Designing and conducting mixed methods research. Thousand Oaks, CA: Sage.

Desidério, P. H. M., \& Popadiuk, S. (2015). Redes de inovação aberta e compartilhamento do conhecimento: Aplicações em pequenas empresas. Revista de Administração e Inovação, 12 (2), 110-129. doi:10.11606/rai.v12i2. 100335

Dias, C. N., Hoffmann, V. E., \& Martínez-Fernández, M. T. (2016, setembro). A influência das redes interorganizacionais e da complementaridade de recursos no desempenho da inovação: Um estudo comparativo Brasil-Espanha no setor de pesquisa agropecuária. Anais do Encontro Nacional da Associação Nacional de Pós-Graduação e Pesquisa em Administração, Costa do Sauípe, BA, Brasil, 40.

Ebers, M. (2015). Interorganizational relationships and networks. In J. D. Wright. International encyclopedia of the social \& behavioral sciences (2nd ed.). Orlando: Elsevier.

Eisenhardt, K. M. (1989). Building theories from case study research. Academy of Management Review, 14(4), 532-550. doi:10.2307/258557 
Engelman, R., Fracasso, E. M., \& Brasil, V. S. (2011). A qualidade percebida nos serviços de incubação de empresas. Revista Eletrônica de Administração, 17(3), 802-822. doi:10.1590/S1413-23112011000300009

Franco, M. R., \& Haase, H. (2011). Network embeddedness: A qualitative study of small technology-based firms. International Journal of Management and Enterprise Development, 11 (1), 34-51. doi:10.1504/IJMED.2011.042971

Giglio, E. M., \& Macau, F. R. (2015). Networks: The facts, the format, the concepts. In E. M. Giglio (Ed.). Business networks: Concepts, methodologies $\mathcal{E}$ research. Rockville: GlobalSouth Press.

Giglio, E. M., Rimoli, C. A., \& Silva, R. D. S. (2008). Reflexões sobre os fatores relevantes no nascimento e no crescimento de redes de negócios na agropecuária. Organizações Rurais \& Agroindustriais, 10(2), 279-292.

Gilsing, V. A., Cloodt, M., \& Bertrand-Cloodt, C. (2016) What makes you more central? Antecedents of changes in betweenness-centrality in technology-based alliance networks. Technological Forecasting \& Social Change, 111, 209-221. doi:10.1016/j.techfore.2016.07.001

Granovetter, M. S. (1973). The strength of weak ties. American Journal of Sociology, 78(6), 1360-1380. doi:10.1086/225469

Godoy, A. S. (2005). Refletindo sobre critérios de qualidade da pesquisa qualitativa. Revista Eletrônica de Gestão Organizacional, 3(2), 80-89.

Grandori, A., \& Soda, G. (1995). Inter-firm networks: antecedents, mechanisms and forms. Organization Studies, 16(2), 183-214. doi:10.1177/ 017084069501600201

Heinze, T., Shapira, P., Rogers, J. D., \& Senker, J. M. (2009). Organizational and institutional influences on creativity in scientific research. Research Policy, 38(4), 610-623. doi:10.1016/j.respol.2009.01.014

Hernandes, J. L. G., \& Giglio, E. M. (2014). Os fatores sociais e de dependência de recursos com condicionantes da emergência de redes de negócio: Discussões a partir do caso da rede de São Roque. Gestão \& Planejamento, 15(2), 261-282.

Klerk, S., \& Kroon, J. (2008). Business networking relationships for business success. South African Journal of Business Management, 39(2), 25-35.

Lacoste, S. (2012). "Vertical coopetition": The key account perspective. Industrial Marketing Management, 41 (4), 649-658. doi:10.1016/j.indmarman. 2011.09.013

Li, L., \& Qian, G. (2008). Partnership or self-reliance entry modes: Large and small technology-based enterprises' strategies in overseas markets. Journal of International Entrepreneurship, 6(4), 188-208. doi:10.1007/s10843008-0029-3 
Limieux, V., \& Ouimet, M. (2008). Análise estrutural das redes sociais. Lisboa: Instituto Piaget.

Lincoln, Y. S., \& Guba, E. G. (1986) But is it rigorous? Trustworthiness and authenticity in naturalistic evaluation. New Directions for Evaluation, 30, 73-84. doi:10.1002/ev.1427

Löfsten, H. (2016). New technology-based firms and their survival: The importance of business networks, and entrepreneurial business behaviour and competition. Local Economy, 31 (3), 393-409. doi:10.1177/02690942 16637334

Mendonça, F. M., Teixeira, M. P. R., Bernardo, D. C. R., \& Fonseca Netto, H. P. (2012). Condicionantes territoriais para formação, desenvolvimento e estruturação de arranjos produtivos locais: Um estudo comparativo em APLs de confecção do Estado de Minas Gerais. Revista de Administração e Inovação, 9(3), 231-256. doi:10.5773/rai.v9i3.913

Morse, J. M. (1991). Approaches to qualitative-quantitative methodological triangulation. Nursing Research, 40(1), 120-123.

Napolitano, L., Evangelou, E., Pugliese, E., Zeppini, P., \& Room, G. (2018). Technology networks: The autocatalytic origins of innovation. Royal Society Open Science, 5(6), 1-17. doi:10.1098/rsos.172445

Nohria, N. (1992). Is a network perspective a useful way of studying organizations? In N. Nohria \& R. G. Eccles (Orgs.). Networks and organizations: Structure, form and action (pp. 287-301). Boston: Harvard Business School.

Nordin, F. (2006). Identifying intraorganisational and interorganisational alliance conflicts: A longitudinal study of an alliance pilot project in the high technology industry. Industrial Marketing Management, 35(2), 116-127. doi:10.1016/j.indmarman.2004.12.010

Paiva, F. G., Jr., \& Fernandes, N. C. M. (2012). A contribuição da competência relacional do empreendedor para aperfeiçoar a qualidade de relacionamento entre empresas de base tecnológica. Revista de Administração e Inovação, 9(3), 53-76. doi:10.5773/rai.v9i3.603

Pereira, B. A. D., Venturini, J. C., Wegner, D., \& Braga, A. L. (2010). Desistência da cooperação e encerramento de redes interorganizacionais: Em que momento essas abordagens se encontram? Revista de Administração e Inovação, 7(1), 62-83. doi:10.5585/rai.v7i1.341

Powell, W. W. (1990). Neither market nor hierarchy: Network forms of organization. Research in Organizational Behavior, 12, 295-336. 
Rimoli, C. A., \& Giglio, E. M. (2008, setembro). Variáveis organizacionais que influenciam o nascimento e o crescimento de redes de pequenas empresas. Anais do Encontro Nacional dos Programas de Pós-Graduação em Administração, Rio de Janeiro, RJ, Brasil, 32.

Scott, J. (2013). Social network analysis (3rd ed.). London: Sage.

Servo, M. L. S., \& Araújo, P. O. (2012). Grupo focal em pesquisas sociais. Revista Espaço Acadêmico, 9(137), 7-15.

Silva, S. I., Veloso A. L., \& Keating, J. B. (2014). Focus group: Considerações teóricas e metodológicas. Revista Lusófona de Educação, 26, 175-190.

Souza, F. A. (2014). Análise da utilização das redes organizacionais por empresas de base tecnológica em um ambiente de inovação aberta. Dissertação de mestrado, Universidade Federal de Itajubá, Itajubá, MG, Brasil.

Steketee, M., Miyaoka, A., \& Spiegelman, M. (2015). Social network analysis. In J. D. Wright. International encyclopedia of the social \& behavioral sciences (2nd ed.). Orlando: Elsevier.

Tálamo, J. R., \& Carvalho, M. M. D. (2012). Cooperação com empresas de base tecnológica: Pesquisa-ação no setor elétrico. Gestão \& Produção, 19(2), 433-444.

Valério Netto, A. (2006). Gestão de pequenas e médias empresas de base tecnológica. Barueri: Minha Editora.

Vergara, S. C. (2015). Métodos de pesquisa em Administração (6a ed.). São Paulo: Atlas.

Wegner, D., \& Padula, A. D. (2012). Quando a cooperação falha: Um estudo de caso sobre o fracasso de uma rede interorganizacional. Revista de Administração Mackenzie, 13(1), 145-171. doi:10.1590/S1678-69712012 000100007

Xavier, J. L. J., Filho, Paiva, F. G., Jr., Alves, S., \& Medeiros, J. J. (2015). Desistência de cooperação em redes interorganizacionais: Reflexões inspiradas na ação social weberiana. Revista de Administração Mackenzie, 16(6), 159-190. doi:10.1590/1678-69712015/administracao.v16n6p159-189

\section{AUTHOR NOTES}

Andréa A. C. Mineiro, Department of Business Administration, Federal University of Lavras (UFLA); Donizeti L. Souza, Department of Business Administration and Economics, Federal University of Lavras (UFLA); Luiz G. R. Antunes, Department of Business Administration, 


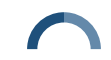

Andréa A. C. Mineiro, Donizeti L. Souza, Luiz G. R. Antunes, Cleber C. Castro

Federal University of Lavras (UFLA); \& Cleber C. Castro, Agribusiness Management Department, Federal University of Rio Grande do Sul (UFRGS).

Andréa A. C. Mineiro is now Professor at the Department of Business Administration and Production Engineering at Federal University at Itajubá (UNIFEI); Donizeti L. Souza is now Professor at the Department of Business Administration at Federal Institute of Education, Science and Technology of South of Minas Gerais (IFMG); Luiz G. R. Antunes is now Substitut Professor of Managment Area at Federal Institute of Education, Science and Technology of South of Minas Gerais (IFMG); \& Cleber C. Castro is now Professor at Agribusiness Management Department (DGA) at Federal University of Lavras (UFLA).

Correspondence concerning this article should be addressed to Andréa A. C. Mineiro, Avenida BPS, 1301, Pinheirinho, Itajubá, Minas Gerais, Brazil, CEP: 37500-903.

E-mail: andreamineiro@unifei.edu.br

\section{EDITORIAL BOARD}

Editors-in-chief

Janette Brunstein

Silvio Popadiuk

Associated Editor

Thais Vick

Technical Support

Vitória Batista Santos Silva

\section{EDITORIAL PRODUCTION}

Publishing Coordination

Irina Migliari

Layout Designer

Emap

\section{Copyeditor}

Irina Migliari (English)

Graphic Designer

Libro

Carlos Villarruel (Portuguese)

Language Editor

Daniel de Almeida Leão (English)

Irina Migliari (Portuguese) 